\title{
High-sensitivity C-reactive protein as a prognostic marker in patients undergoing valve surgery
}

\author{
Piotr Duchnowski, Piotr Szymański, Mariusz Kuśmierczyk, Tomasz Hryniewiecki \\ Department of Acquired Cardiac Defects, Institute of Cardiology, Warsaw, Poland
}

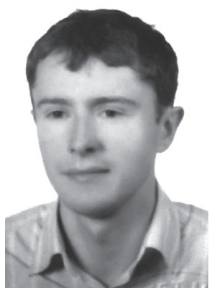

Kardiochir Torakochir Pol 2020; 17 (1): 15-19

\begin{abstract}
Introduction: An inflammatory reaction is a local or systemic response of the organs or tissues of the body to many damaging factors. One of the exponents of the inflammatory process is C-reactive protein (CRP).

Aim: To investigate the prognostic value of C-reactive protein (CRP) in patients undergoing valve surgery.

Material and methods: A prospective study was conducted on a group of consecutive patients with haemodynamically significant valve defects who underwent elective valve repair or replacement surgery. The primary end-point was in-hospital death from all causes. Patients were followed by direct observation during hospitalization. The risk of surgery using EuroSCORE II was calculated for each patient. The plasma levels of C-reactive protein were measured by the Cardiac C-Reactive Protein (Latex) High Sensitive Test (Roche, Germany).

Results: The study group included 562 patients. The mean age in the studied population was 63 (standard deviation (SD) \pm 12 ). The mean plasma preoperative CRP level was $0.39 \pm 0.3 \mathrm{mg} / \mathrm{dl}$. The primary endpoint occurred in 25 patients. At multivariate analysis age $(p=0.01), \operatorname{CRP}(p=0.02)$ and NT-proBNP $(p=0.03)$ remained independent predictors of the primary endpoint. A significant correlation was found between the level of CRP and haemoglobin $(r=-0.3 ; p<0.0001)$, red cell distribution width $(r=0.22 ; p<0.0001)$, ejection fraction $(r=-0.24, p=0.007)$, troponin $\mathrm{T}(r=0.3 ; p<0.0001)$, creatinine $(r=0.26 ; p=0.001)$ and body mass index $(r=-0.29 ; p=0.005)$. The average total time of hospitalization after the operation in patients with occurrence of the primary endpoint was $25 \pm 13$ days.

Conclusions: Elevated preoperative CRP was associated with a poorer outcome following valve surgery.
\end{abstract}

Key words: C-reactive protein, CRP, valve surgery, predictors.

\section{Streszczenie}

Wprowadzenie: Proces zapalny jest miejscową lub ogólnoustrojową odpowiedzią tkanek i/lub narządów na działanie licznych czynników uszkadzających. Jednym z wykładników procesu zapalnego jest białko C-reaktywne (CRP).

Cel pracy: Ocena wartości prognostycznej CRP u pacjentów poddawanych kardiochirurgicznym operacjom zastawkowym serca.

Materiat i metody: Badanie prospektywne przeprowadzone w grupie kolejnych pacjentów z istotną hemodynamicznie wadą zastawkową serca, poddanych klasycznej operacji naprawy i/lub wymiany zastawki lub zastawek. Głównym punktem końcowym w obserwacji wewnątrzszpitalnej był zgon z każdej przyczyny. W każdym przypadku ryzyko operacji obliczono przy użyciu kalkulatora EuroSCORE II. Stężenie CRP w osoczu oznaczono za pomocą testu Cardiac C-Reactive Protein (Latex) High Sensitive Test (Roche, Niemcy).

Wyniki: W badaniu wzięło udział 562 pacjentów. Średni wiek w badanej populacji wynosił $63 \pm 12$ lat. Średnia wartość CRP kształtowała się na poziomie 0,39 $\pm 0,3 \mathrm{mg} / \mathrm{dl}$. Główny punkt końcowy wystąpił u 25 pacjentów. W analizie wieloczynnikowej wiek $(p=0,01), \operatorname{CRP}(p=0,02)$ oraz NT-proBNP $(p=0,03)$ byty niezależnymi predyktorami głównego punktu końcowego. Stwierdzono istotną korelację między stężeniem CRP a stężeniami hemoglobiny $(r=-0,3 ; p<0,0001)$, troponiny $T(r=0,3 ; p<0,0001)$, kreatyniny $(r=0,26 ; p=0,001)$, rozpiętością rozkładu objętości erytrocytów ( $r=0,22 ; p<0,0001)$, frakcją wyrzutową lewej komory $(r=-0,24, p=0,007)$ oraz wskaźnikiem masy ciała $(r=-0,29 ; p=0,005)$. Średni okres hospitalizacji po zabiegu chirurgicznym u pacjentów, u których obserwowano wystąpienie głównego punktu końcowego, wynosił $25 \pm 13$ dni. Wnioski: Podwyższone przedoperacyjne stężenie CRP może się wiązać z gorszym wynikiem operacji zastawkowej serca.

Słowa kluczowe: białko C-reaktywne, CRP, operacja zastawkowa, predyktory.

Address for correspondence: Piotr Duchnowski MD, PhD, Department of Acquired Cardiac Defects, Institute of Cardiology, 42 Alpejska St, 04-628 Warsaw, Poland, e-mail: duchnowski@vp.pl

Received: 14.11.2019, accepted: 23.02.2020. 


\section{Introduction}

Risk stratification applies to all types of interventions and forms the basis for making decisions [1]. The risk assessment of cardiac surgery involves risk calculators - in European conditions it is most often EuroSCORE II [2]. In practice, however, the risk calculators have many different limitations. They do not always accurately assess the severity of the disease and do not cover many important risk factors, such as the presence of the fragility syndrome. In clinical practice in various areas of cardiology, the risk assessment strategy using biological markers is of great interest $[3,4]$. C-reactive protein (CRP) is one of the most

Table I. Baseline characteristics of the study population $(n=562)$

\begin{tabular}{|c|c|}
\hline Characteristics of patients & Values \\
\hline Age [years] ${ }^{*}$ & $63 \pm 12$ \\
\hline Male: men, $n(\%)$ & $331(58)$ \\
\hline Stroke in history, $n(\%)$ & $43(7)$ \\
\hline Atrial fibrillation, $n(\%)$ & $241(42)$ \\
\hline Coronary artery disease, $n(\%)$ & $95(17)$ \\
\hline Peripheral atherosclerosis, $n$ (\%) & $39(6)$ \\
\hline Diabetes mellitus, $n(\%)$ & 105 (18) \\
\hline Hypertension, $n$ (\%) & $375(66)$ \\
\hline Body mass index $\left[\mathrm{kg} / \mathrm{m}^{2}\right]^{*}$ & $27.6 \pm 10$ \\
\hline Chronic obstructive airways disease, $n(\%)$ & $40(7)$ \\
\hline $\begin{array}{l}\text { Chronic kidney disease } \\
\left(\mathrm{GFR}<60 \mathrm{ml} / \mathrm{min} / 1.73 \mathrm{~m}^{2}\right), n(\%)\end{array}$ & $183(32)$ \\
\hline LV ejection fraction (\%)* & $57 \pm 10$ \\
\hline Pulmonary blood pressure $[\mathrm{mm} \mathrm{Hg}]^{*}$ & $43 \pm 18$ \\
\hline NYHA (classes)* & $2.4 \pm 0.5$ \\
\hline EuroSCORE II & $3.5 \pm 3.2$ \\
\hline Haemoglobin $[\mathrm{g} / \mathrm{dl}]^{*}$ & $13.6 \pm 2.6$ \\
\hline Red cell distribution width (\%)* & $14 \pm 1.4$ \\
\hline NT-proBNP [pg/ml] ${ }^{\star}$ & $1834 \pm 1230$ \\
\hline $\mathrm{TnT}[\mathrm{ng} / \mathrm{l}]$ & $37 \pm 28$ \\
\hline CRP [mg/dl] & $0.39 \pm 0.3$ \\
\hline Creatinine $[\mathrm{md} / \mathrm{dl}]^{*}$ & $0.8 \pm 0.6$ \\
\hline Aortic cross-clamp time $[\mathrm{min}]^{*}$ & $93 \pm 41$ \\
\hline 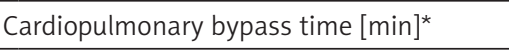 & $117 \pm 45$ \\
\hline Days at the ICU [days] ${ }^{*}$ & $5 \pm 3$ \\
\hline $\begin{array}{l}\text { Overall duration of hospitalization } \\
\text { after surgery [days] }\end{array}$ & $12 \pm 9$ \\
\hline \multicolumn{2}{|l|}{ Main procedures: } \\
\hline AVR, $n(\%)$ & $307(55.5)$ \\
\hline$M V R, n(\%)$ & $106(20.6)$ \\
\hline MVR + AVR, $n(\%)$ & $43(6)$ \\
\hline MVP, $n(\%)$ & $106(17.7)$ \\
\hline
\end{tabular}

Values are represented by the mean* and a measure of the variation of the internal standard deviation. AVR - aortic valve replacement, MVP - mitral valve plasty, MVR - mitral valve replacement, ICU - intensive care unit, GFR glomerular filtration rate, CRP - C-reactive protein, TnT - troponin T, LV - left ventricle, NT-proBNP - N-terminal of the prohormone brain natriuretic peptide, NYHA - New York Heart Association. important acute phase proteins. To date, numerous publications have shown a significant relationship between elevated CRP values and worse prognosis in patients with hypertension, myocardial infarction, chronic heart failure or diabetes mellitus $[5,6]$. On the other hand, information on the predictive capacity of CRP in patients with valvular heart disease is limited.

\section{Aim}

Due to the need to supplement reliable tools for risk assessment in patients undergoing heart valve surgery in the present study, we tried to check the suitability of the CRP parameter for predicting death in in-hospital observation in this group of patients.

\section{Material and methods}

The present prospective study was conducted on a group of consecutive patients with haemodynamically significant valve disease (aortic stenosis, aortic regurgitation, mitral stenosis and mitral regurgitation) who underwent a replacement or repair of the valve. The exclusion criteria were: patients under 18 years of age, a lack of consent to participate in the study, active neoplastic diseases and active endocarditis. The risk of surgery using EuroSCORE II was calculated for each patient. The day before surgery a blood sample for biomarkers was collected from each patient. Complete blood count was performed with K2-EDTA samples, using a Cobas 6000 electronic counter (Roche, Mannheim, Germany). The plasma levels of C-reactive protein were measured by the Cardiac C-Reactive Protein (Latex) High Sensitive Test (Roche, Germany), the plasma levels of NT-proBNP were measured by the electrochemiluminescent immunoassays Elecsys 2010 (Roche, Germany) and the plasma levels of high-sensitivity troponin T (TnT) were measured by the Troponin T hs-STAT (Roche, Germany). Baseline characteristics of the patients are presented in Table I. The mean age in the studied population was $63 \pm 12$. The mean plasma preoperative CRP level was $0.39 \pm 0.3 \mathrm{mg} / \mathrm{dl}$. All procedures were performed through a midline sternotomy incision under general anaesthesia in normothermia. All patients were given cold blood cardioplegia at the initial dose of 15-20 ml/kg followed by booster doses of 5-10 ml/kg every 20 minutes. The primary end-point was in-hospital death from all causes. Patients were followed by direct observation during hospitalization. The study was conducted at the Institute of Cardiology, Warsaw. The protocol was approved by the Institutional Ethics Committee.

\section{Statistical analysis}

All analyses were performed using SAS version 9.2. Intergroup comparisons were made using the Pearson $\chi^{2}$ test or Student's $t$ test. Logistic regression was used to assess relationships between variables. The pre-operative covariates age, body mass index, atrial fibrillation, diabetes mellitus, hypertension, peripheral atherosclerosis, bilirubin, creatinine, CRP, troponin $\mathrm{T}(\mathrm{TnT}), \mathrm{N}$-terminal of the pro- 
hormone brain natriuretic peptide (NT-proBNP), as well as intraoperative covariates such as aortic cross-clamp time and cardiopulmonary bypass time, were investigated for association with the endpoint in univariate analysis. Significant determinants $(p<0.05)$ identified from univariate analysis were subsequently entered into multivariate models. Spearman's rank correlation coefficient was used to search for associations between the pre-operative serum CRP level and haemoglobin, red cell distribution width (RDW), left ventricle ejection fraction (LVEF), TnT, creatinine and body mass index (BMI). The cut-off point for the CRP parameter which fulfils the criterion of maximum sensitivity and specificity for the primary endpoint was determined based on the Youden index.

\section{Results}

The study included 562 patients who underwent valve surgery. The primary end-point occurred in 25 patients as a result of gradually increasing multi-organ failure. The actual in-hospital mortality was $4.4 \%$ vs the mortality $3.5 \%$ predicted by the EuroSCORE II model. Statistically significant predictors of primary end-point in univariate analysis are presented in Table II. In multivariate analysis age $(\mathrm{OR}=1.068 ; 95 \% \mathrm{Cl}: 1.015-1.124 ; p=0.01), \mathrm{CRP}(\mathrm{OR}=1.410$; $95 \% \mathrm{Cl}: 1.038-1.916 ; p=0.02)$, and NT-proBNP (OR $=1.010$; 95\% Cl: 1.002-1.022; $p=0.03$ ) remained independent predictors of the primary endpoint. The optimal cut-off point for the primary end-point was calculated at $0.5 \mathrm{mg} / \mathrm{dl}$. The area under the receiver operator characteristic curve for in-hospital death for CRP is 0.773 (95\% Cl: 0.736-0.808) (Figure 1). A significant correlation was found between the level of CRP and haemoglobin $(r=-0.3 ; p<0.0001)$, RDW $(r=0.22 ; p<0.0001), \mathrm{EF}(r=-0.24, p=0.007), \operatorname{TnT}(r=0.3$; $p<0.0001)$, creatinine $(r=0.26 ; p=0.001)$ and BMI $(r=-0.29 ; p=0.005)$. The mean value of preoperative hsCRP in the group of patients who died in the postoperative period was $1.03 \pm 0.55$ and was significantly higher compared to patients who survived $0.35 \pm 0.3(p=0.005)$. In addition, patients who died were older $(71 \pm 14$ vs. $62 \pm 12$; $p=0.01$ ), were characterized by a higher incidence of chronic diseases such as coronary artery disease ( $33 \%$ vs. $14 \%$; $p=0.03)$, chronic kidney disease ( $46 \%$ vs. $30 \% ; p=0.02$ ), atrial fibrillation (61\% vs. $41 \%$; $p=0.02)$ or diabetes $(24 \%$ vs. $17 \% ; p=0.04)$. The risk of surgery calculated using the EurOSCORE II calculator in the group of patients who died was on average $7.4 \pm 5 \%$ and was significantly higher compared to patients who survived, $2.9 \pm 2.5$. The average stay in the intensive care unit in the group of patients who finally died was $25 \pm 17$ days and was significantly longer compared to patients who survived $4 \pm 2$.

\section{Discussion}

An inflammatory reaction is a local or systemic response of the organs or tissues of the body to many damaging factors. The intensity of the inflammatory reaction in the tissue or organ structure depends on the efficiency of
Table II. Univariate analysis of predictive factors for occurrence of the primary endpoint

\begin{tabular}{lccc} 
Variable & Odds ratio & $95 \% \mathrm{Cl}$ & $P$-value \\
Age [years] & 1.080 & $1.031-1.132$ & 0.001 \\
\hline CRP $[\mathrm{mg} / \mathrm{dl}]$ & 1.647 & $1.276-2.126$ & 0.001 \\
\hline NT-proBNP $[\mathrm{pg} / \mathrm{ml}]$ & 1.011 & $1.002-1.023$ & 0.004 \\
\hline Hs-TnT $[\mathrm{ng} / \mathrm{l}]$ & 1.025 & $1.006-1.043$ & 0.008 \\
\hline Creatinine $[\mathrm{mg} / \mathrm{dl}]$ & 0.979 & $0.969-0.959$ & 0.001 \\
\hline
\end{tabular}

CRP - C-reactive protein, NT-proBNP - N-terminal of the prohormone brain natriuretic peptide, $\mathrm{TnT}$ - troponin $\mathrm{T}$.

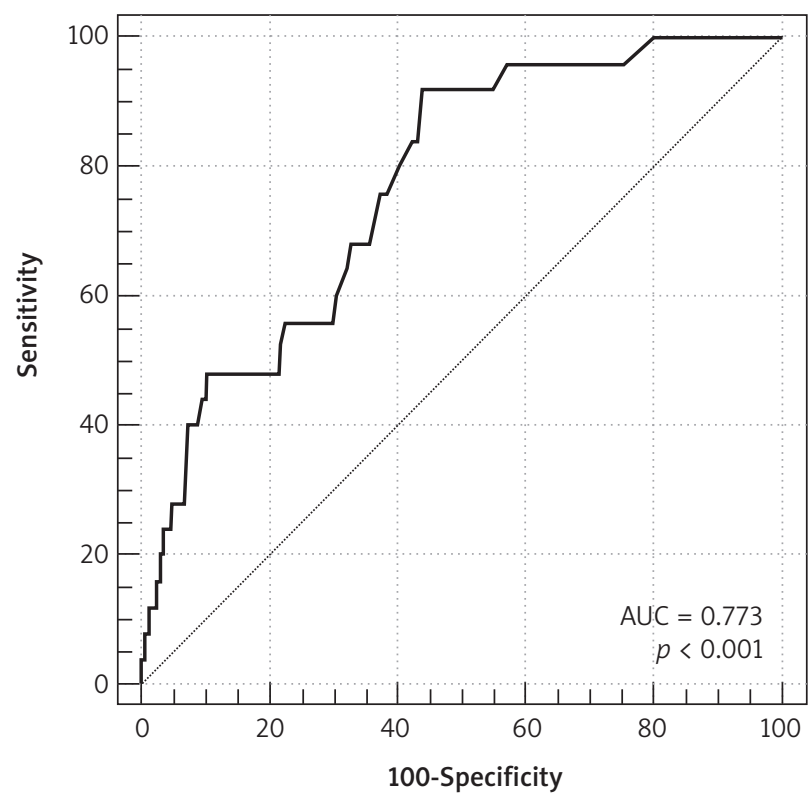

Figure 1. Area under receiver operating characteristic curve of preoperative CRP for in-hospital death following valve replacement/ repair surgery

the body's immune mechanisms, which limit the extent of this process. The presence of the inflammatory process is associated with the dominance of catabolic processes consuming energy reserves, as well as causing the breakdown of storage and structural proteins [7, 8]. Chronic inflammation is a process described in many disease entities. One of the exponents of the inflammatory process is CRP. CRP is a cyclic pentamer that binds ligands in calcium-dependent reactions [9]. CRP is also one of the most important acute phase proteins whose role is to participate in the body's immune response by facilitating complement fixation and thus opsonization and phagocytosis [10]. CRP is produced in the liver as a result of induction by IL-1 and IL-6. Numerous publications have shown that the presence of inflammation in the body is associated with increased morbidity and mortality [11-14]. It was also described that an elevated CRP value is a predictor of inferior physical fitness and cognitive functions [7]. The lowest levels of CRP are found in people with normal body mass. The relationship between BMI and proinflammatory factors takes the form of the letter U. People with the lowest morbidity and mortality are characterized by normal weight or overweight. Persons 
in extreme weight groups are at least partially characterized by systemic inflammation $[15,16]$. It has been demonstrated so far that elevated CRP values determined after transapical transcatheter aortic valve implantation are associated with worse prognosis [17]. On the other hand, in a study of a group of 416 patients with valvular heart disease, pre-operative CRP values were significantly correlated with the incidence of major postoperative complications in the 30-day observation [6]. In this study, however, due to the limited number of patients, the authors did not assess the usefulness of the CRP parameter as a predictor of only in-hospital death.

Not all patients with elevated CRP values are characterized by increased morbidity. The available literature suggests that morbidity in patients with elevated inflammatory parameters results from the balance between numerous proinflammatory and anti-inflammatory factors [18]. In addition, modifiable factors such as diet, physical activity levels, fat content in the body, smoking or genetic background may play an important role [19-21]. In the present study we found that the pre-operative level of CRP is an independent predictor of in-hospital death in patients undergoing heart valve surgery. It is worth noting that in the whole group of 25 patients in whom in-hospital death was observed, the cause of fatal outcome was a gradually increasing multiple organ dysfunction syndrome. It is also worth paying attention to the fact that the patients who died were older and were characterized by more frequent co-occurrence of chronic diseases such as diabetes, chronic kidney disease or atrial fibrillation in comparison to survivors. A healthy organism has properly functioning mechanisms that maintain its homeostasis and enable its adaptation to the environment, which is especially important in extreme conditions such as cardiac surgery due to cardiac valvular disease [8]. The results of the present study indicate that the ongoing inflammatory process is associated with worse work of individual organs and systems, as indicated by the significant correlation demonstrated between CRP and haemoglobin, RDW, LVEF, TnT, creatinine and BMI parameters, which may have a decisive effect on the cardiosurgical treatment. And although fairly good calibration and discrimination of the EuroSCORE II calculator have been confirmed in the group of Polish patients undergoing cardiac surgery, information about the predictive ability of the CRP parameter may be useful for doctors both during the process of qualifying patients for cardiac surgery and in the postoperative period during patient care in intensive care unit therapy $[2,22,23]$.

\section{Conclusions}

The inflammatory process is a local or systemic response of the organs or tissues of the body to many damaging factors. One of the exponents of the inflammatory process is C-reactive protein. The present paper is one of the first to indicate the hs-CRP parameter as an independent predictor of the occurrence of a hard endpoint in the form of in-hospital death in patients undergoing heart valve surgery, which can be helpful both during the qualification process for surgical treatment and in the postoperative period when particular attention should be paid to this, especially in patients at risk.

\section{Disclosure}

The authors report no conflict of interest.

\section{References}

1. Baumgartner H, Falk V, Bax J, De Bonis M, Hamm C, Holm PJ, lung B, Lancellotti P, Lansac E, Rodriguez Muńoz D, Rosenhek R, Sjögren J, Tornos Mas P, Vahanian A, Walther T, Wendler O, Windecker S, Zamorano JL; ESC Scientific Document Group. ESC/EACTS Guidelines for the management of valvular heart disease. Eur Heart J 2017; 38: 2739-2791.

2. Duchnowski P, Hryniewiecki T, Kuśmierczyk M, Szymański P. Performance of the EuroSCORE II and the Society of Thoracic Surgeons score in patients undergoing aortic valve replacement for aortic stenosis. J Thorac Dis 2019; 11: 2076-2081.

3. Duchnowski P, Hryniewiecki T, Koźma M, Mariusz K, Piotr S. High-sensitivity troponin $T$ is a prognostic marker of hemodynamic instability in patients undergoing valve surgery. Biomark Med 2018; 12: 1303-1309.

4. Petaja L, Rosio H, Mildh L, Suojaranta-Ylinen R, Kaukonen KM, Jokinen JJ, Salmenperä M, Hagve TA, Omland T, Pettilä V. Predictive value of high-sensitivity troponin $\mathrm{T}$ in addition to EuroSCORE II in cardiac surgery. Interact Cardiovasc Thorac Surg 2016; 23: 133-141.

5. Ridker PM. A test in context: high-sensitivity c-reactive protein. J Am Coll Cardiol 2016; 67: 712-723.

6. Duchnowski P, Hryniewiecki T, Kuśmierczyk M, Szymański P. The usefulness of selected biomarkers in patients with valve disease. Biomark Med 2018; 12: 1341-1346.

7. Velissaris D, Pantzaris N, Koniari I, Koutsogiannis N, Karamouzos V, Kotroni I, Skroumpelou A, Ellul J. C-reactive protein and frailty in the elderly: a literature review. J Clin Med Res 2017; 9: 461-465.

8. Całkosiński I, Dobrzyński M, Całkosińska M, Seweryn E, Bronowicka-Szydełko A, Dzierzba K, Ceremuga I, Gamian A. Characterization of an inflammatory response. Postepy Hig Med Dosw 2009; 63: 395-408.

9. Osmand AP, Friedenson B, Gewurz H, Painter RH, Hofmann T, Shelton E. Characterization of $\mathrm{C}$-reactive protein and the complement subcomponent C1t as homologous proteins displaying cyclic pentameric symmetry (pentraxins). Proc Natl Acad Sci USA 1977; 74: 739-743.

10. Volanakis JE. Human C-reactive protein: expression, structure, and function. Mol Immunol 2001; 38: 189-197.

11. Rohde LE, Hennekens CH, Ridker PM. Survey of C-reactive protein and cardiovascular risk factors in apparently healthy men. Am J Cardiol 1999; 84: 1018-1022.

12. Duchnowski P, Hryniewiecki T, Kuśmierczyk M, Szymanski P. Red cell distribution width as a predictor multiple organ dysfunction syndrome in patients undergoing heart valve surgery. Biol Open 2018; 7: pii: bio036251.

13. Adukauskienė D, Čiginskienè A, Adukauskaitė A, Pentiokinienė D, Šlapikas R, Čeponienè I. Clinical relevance of high sensitivity C-reactive protein in cardiology. Medicina 2016; 52: 1-10.

14. de Boer RA, Nayor M, de Filippi CR, Enserro D, Bhambhani V, Kizer JR, Blaha MJ, Brouwers FP, Cushman M, Lima JAC, Bahrami H, van der Harst P, Wang TJ, Gansevoort RT, Fox CS, Gaggin HK, Kop WJ, Liu K, Vasan RS, Psaty BM, Lee DS, Hillege H, Bartz TM, Benjamin EJ, Chan C, Allison M, Gardin JM, Januzzi JL Jr, Shah SJ, Levy D, Herrington DM, Larson MG, van Gilst WH, Gottdiener JS, Bertoni AG, Ho JE. Association of cardiovascular biomarkers with incident heart failure with preserved and reduced ejection fraction. JAMA Cardiol 2018; 3: 215-224.

15. Akin I, Nienaber CA. "Obesity paradox" in coronary artery disease. World J Cardol 2015; 7: 603-608.

16. Costanzo P, Cleland JG, Pellicori P, Clark AL, Hepburn D, Kilpatrick ES, Perrone-Filardi P, Zhang J, Atkin SL. The obesity paradox in type 2 diabetes mellitus: relationship of body mass index to prognosis: a cohort study. Ann Intern Med 2015; 162: 610-618.

17. Rettig T, Rigter S, Nijenhuis V, van Kuijk JP, ten Berg JM, Heijmen RH, van de Garde EM, Noordzij PG. The systemic inflammatory response syndrome 
predicts short-term outcome after transapical transcatheter aortic valve implantation. J Cardiothorac Vasc Anesth 2015; 29: 283-287.

18. Beyer I, Njemini R, Bautmans I, Demanet C, Bergmann P, Mets T. Inflammation-related muscle weakness and fatigue in geriatric patients. Exp Gerontol 2012; 47: 52-59.

19. Duchnowski P, Hryniewiecki T, Stokłosa P, Kuśmierczyk M, Szymański P. Number of erythrocytes as a prognostic marker in patients undergoing heart valve surgery. Kardiol Pol 2018; 76: 791-793.

20. D Attaix L, Mosoni D, Dardevet L, Combaret L, Mirand PP, Grizard J. Altered responses in skeletal muscle protein turnover during aging in anabolic and catabolic periods. Int J Biochem Cell Biol 2005; 37: 1962-1973.
21. Esposito K, Pontillo A, Di Palo C, Giugliano G, Masella M, Marfella R, Giugliano D. Effect of weight loss and lifestyle changes on vascular inflammatory markers in obese women: a randomized trial. JAMA 2003; 289: 1799-1804.

22. Knapik P, Cieśla D, Saucha W, Knapik M, Zembala MO, Przybyłowski $P$, Kapelak B, Kuśmierczyk M, Jasiński M, Tobota Z, Maruszewski BJ, Zembala $\mathrm{M}$; KROK Investigators. Outcome prediction after coronary surgery and redo surgery for bleeding (From the KROK Registry). J Cardiothorac Vasc Anesth 2019; 33: 2930-2937.

23. Duchnowski P, Hryniewiecki T, Kuśmierczyk M, Żebrowska A, Kuśmierczyk M, Szymański P. High-sensitivity troponin T as a prognostic marker in patients undergoing aortic valve replacement. Pol Arch Intern Med 2017; 127: 628-630. 